Article

\title{
Exploring the Salient Attributes of Short-Term Rental Experience: An Analysis of Online Reviews from Chinese Guests
}

\author{
Yuanyuan Guo ${ }^{1,2}$, Yanqing Wang ${ }^{1}$ and Chaoyou Wang ${ }^{3, *}$ \\ 1 School of Maritime Economics and Management, Dalian Maritime University, Dalian 116026, China \\ 2 Collaborative Innovation Center for Transport Studies, Dalian Maritime University, Dalian 116026, China \\ 3 School of Management Science and Engineering, Dongbei University of Finance and Economics, \\ Dalian 116025, China \\ * Correspondence: wangchaoyou@hotmail.com
}

Received: 23 July 2019; Accepted: 6 August 2019; Published: 8 August 2019

\begin{abstract}
Although China has become an emerging market in the peer-to-peer (P2P) accommodation industry, no research has been conducted to examine Chinese guests' experience with short-term rentals. This study aims to investigate major service attributes that influence Chinese guests' experiences and satisfaction with P2P accommodations by analyzing online reviews on the Xiaozhu sharing economy platform in China. Using text mining and content analysis method, the study found that Chinese guests who stayed in entire houses/apartments and private rooms frequently mentioned "host service," "cleanliness," "location and transportation," and "living environment." In addition, the guests who stayed in private rooms cared more about "security and privacy" and "value for money." Those who stayed in entire houses cared more about the facilities, with a particular focus on the aspects of the kitchen. Finally, the guests who stayed in private rooms valued social interaction with the host more and left a lower proportion of negative reviews related to "host service" than those who stayed in entire houses. This study provides a comprehensive understanding of the Chinese guests' experience.
\end{abstract}

Keywords: sharing economy; short-term rental; peer-to-peer accommodation; customer experience; online review; Chinese guest; entire house; private room

\section{Introduction}

The sharing economy, such as peer-to-peer (P2P) accommodation, is driven by people's pursuit of sustainability, economic gain, and individual enjoyment [1]. It has aroused great interest among researchers and businesses. The sharing economy refers to individual coordinating the distribution of a resource sitting idly for a fee or other compensation [2,3]. The fast development of P2P platforms, such as Airbnb, makes short-term rental one of the fastest growing markets of the sharing economy [4]. In the summer of 2015, the number of guests stayed with Airbnb has already exceeded 17 million worldwide, which is nearly four times than in 2010 [5]. We focus on Xiaozhu, a representative of P2P online platform provider in China. In China, short-term rental services are found to be able to promote property sales, and have been forming a unique local characteristics [6].

Despite the development of the literature on how to improve guests' experience and satisfaction with P2P accommodations [7-14], these studies have focused on Western countries instead of those of Asia (China in particular). Cheng and Jin [9] suggested that context, such as the general multiculturality and safety of an environment, can influence the attributes of short-term rental experiences. P2P accommodations entail a stranger-stranger transaction, which requires trust between the host and guest [15-24]. However, unlike in the Western market, interpersonal trust and safety are lower in 
China. This may lead to customers experiencing P2P accommodations differently. Thus, one purpose of this study is to explore the major attributes influencing Chinese guests' experience and satisfaction with P2P accommodations by analyzing online reviews from Chinese guests.

Studies have identified several attributes affecting customers' experience with P2P accommodations. Such studies have highlighted similar but sometimes contradictory evidence. For example, Belarmino et al. [25] suggested that guests' motivations to select a P2P accommodation are different from hotel guests. However, other scholars argue that P2P accommodation is just a hotel-like experience at a cheaper price [10]. In addition, some scholars suggest that low cost is a major cause for individuals choosing P2P accommodations [10,26]. Contrarily, Cheng and Jin [9] suggested that price is not a key influencer of P2P guests' experiences. Finally, Guttentag et al. [12] suggested that P2P guests pay more attention to practical than experiential attributes. However, the impact of location, a practical attribute, on Airbnb customers' satisfaction has been found to be insignificant, whereas enjoyment, economic benefits, and amenities have been found to be significantly influence customers' satisfaction [27]. Some scholars have suggested that the reason for these contradictory findings may be the lack of standards among Airbnb accommodations [13], travel desires and consumer personalities [10]. This study aims to explore the reasons for these contradictory evidences. We argue that guests of different accommodation types pay attention to different attributes of P2P accommodations. As shown on the Airbnb and Xiaozhu websites, two main types of P2P accommodations exist, namely entire houses/apartments and private rooms. Entire houses are usually rented by families or groups of friends. In this case, the guests do not need to share the accommodations with the host or other tenants. Private rooms are single rooms for one guest at a lower price. In this case, the guest has to share the house with the landlord/host or other customers. Those who stay in entire houses and private rooms may have different P2P accommodation experiences. Thus, the other purpose of this study is to explore the reasons for various debates relating to $\mathrm{P} 2 \mathrm{P}$ accommodation experiences by investigating the Chinese guests' experience and satisfaction with entire houses and private rooms separately. The findings could extend the hospitality literature and sharing economy by providing a comprehensive understanding of Chinese customers' experience with P2P accommodations.

This paper is structured as follows. Firstly, a literature review relating to customers' experiences of $\mathrm{P} 2 \mathrm{P}$ accommodations and online customer reviews is presented. We then describe the process of data collection and data analysis. Next, text-mining results and sentiment analysis results are presented. Finally, we discuss the findings, implications, and future directions.

\section{Literature Review}

\subsection{Customers' Experiences of Peer-to-Peer Accommodations}

The hospitality research includes a large body of literature investigating the attributes contributing to customers' satisfaction, quality of experience, hotel selection, and purchase intention [28-32]. Some factors such as services, location, room, food and beverage, hotel image, value for money, security, and hotel marketing are considered as key attributes influencing a customer's decision to choose a hotel [33-35].

The rapid development of $\mathrm{P} 2 \mathrm{P}$ accommodations has gradually made them an alternative accommodation option. Increasingly popular, P2P accommodations challenge the traditional hotel industry $[8,36,37]$. Thus, hotel managers must understand what attributes make P2P accommodations so popular with customers. Several studies have attempted to explore the attributes that affect users' experiences with P2P accommodations and the differences between hotels and P2P accommodations. Commonly established attributes include economic benefits/cheaper price [10], location [9,13,38], household amenities [9,11], cleanliness [8], host-guest interaction $[9,10,38]$, and spending time in local neighborhoods $[7,13]$. In contrast to traditional hotels, Belarmino et al. [25] suggested that Airbnb consumers emphasize the social interactions with hosts, whereas hotel consumers value room attributes more. ModySuess and Lehto [39] revealed that Airbnb visitors value the accommodation experience in 
relation to serendipity, localness, community, and personalization. Cheng and Jin [9] further unpacked the attributes of the Airbnb experience and suggested that the host theme covers various aspects, such as their helpfulness, flexibility, and communication and even the pets they have.

Studies also have highlighted similar but sometimes contradictory evidence. Firstly, some scholars suggest that low cost is a major cause for individual choosing P2P accommodations $[10,26]$. Contrarily, Cheng and Jin [9] suggested that price is not a key influencer of P2P guests' experiences. Secondly, Guttentag et al. [12] suggested that P2P guests pay more attention to practical than experiential attributes. However, the impact of location, a practical attribute, on Airbnb customers' satisfaction has been found to be insignificant, whereas enjoyment, economic benefits, and amenities have been found to be significantly influence customers' satisfaction [27]. This study aims to explore the reasons for these contradictory findings. Although researchers have attempted to understand users' experiences with P2P accommodations, they generally analyzed the experience and satisfaction of customers in Western countries, with no consideration of Chinese guests, who may have different concerns due to differences in culture and social trust.

\subsection{Online Customer Reviews}

Online customer reviews, also often referred to as electronic word-of-mouth (eWOM), are online user-generated product or service evaluations posted online [40]. They provide information related to customers' post-purchase experiences, such as the usage or features of the product or service [41]. If managed and analyzed effectively and appropriately, they can provide significant customer intelligence, which is valuable for tourism and hospitality businesses [13]. Therefore, online customer reviews provide an opportunity for tourism and hospitality operators to better understand customers' experience and satisfaction.

In the hospitality and tourism field, researchers have investigated the role of online reviews in predicting booking intentions or customer satisfaction [41-48]. For example, based on TripAdvisor comments of Hong Kong hotels, Li et al. [35] identified six attributes affecting customers' satisfaction, namely value, location, sleep, room, cleanliness, and service. Based on 60,648 customer reviews of hotels, Xiang et al. [43] suggested six dimensions affecting customer satisfaction, namely hybrid, deals, family friendliness, amenities, core product of a hotel, and perceptions of hotel staff.

Recently, scholars have begun to focus on the online reviews of P2P accommodations $[9,13,49]$. For example, based on 181,263 Airbnb reviews, Cheng and Jin [9] identified three main attributes that consumers care about, namely host, location, and amenities, with price surprisingly not considered as a key attribute. Based on 41,560 reviews from 1617 property listings on Airbnb, Tussyadiah et al. [13] identified three key attributes of P2P accommodation experiences, namely location, property (e.g., facilities and amenities), and host (e.g., service and hospitality). Several studies have found evidence of users' P2P accommodation experiences. However, they are limited in their focus on reviews from customers in Western countries, neglecting the experiences of customers in developing countries, especially Chinese customers.

\section{Methodology}

\subsection{Data Collection}

Online reviews from Xiaozhu, a P2P online platform provider in China, were used, as shown in Figure 1. We selected Xiaozhu because it is a representative of short-term rental platforms in China, connecting hosts who would like to rent their properties to customers who would like to book an accommodation. Scholars have recently begun to choose the Xiaozhu platform as a research setting, such as Wang et al. [50]. Since its inception in Beijing in 2012, it has experienced explosive growth, connecting more than 420,000 houses worldwide and covering 400 cities in China and 252 destinations overseas [51]. We expand the geographic scope of the studies relating to the sharing economy by investigating China's P2P accommodation market, instead of those in Europe and the U.S.A. 


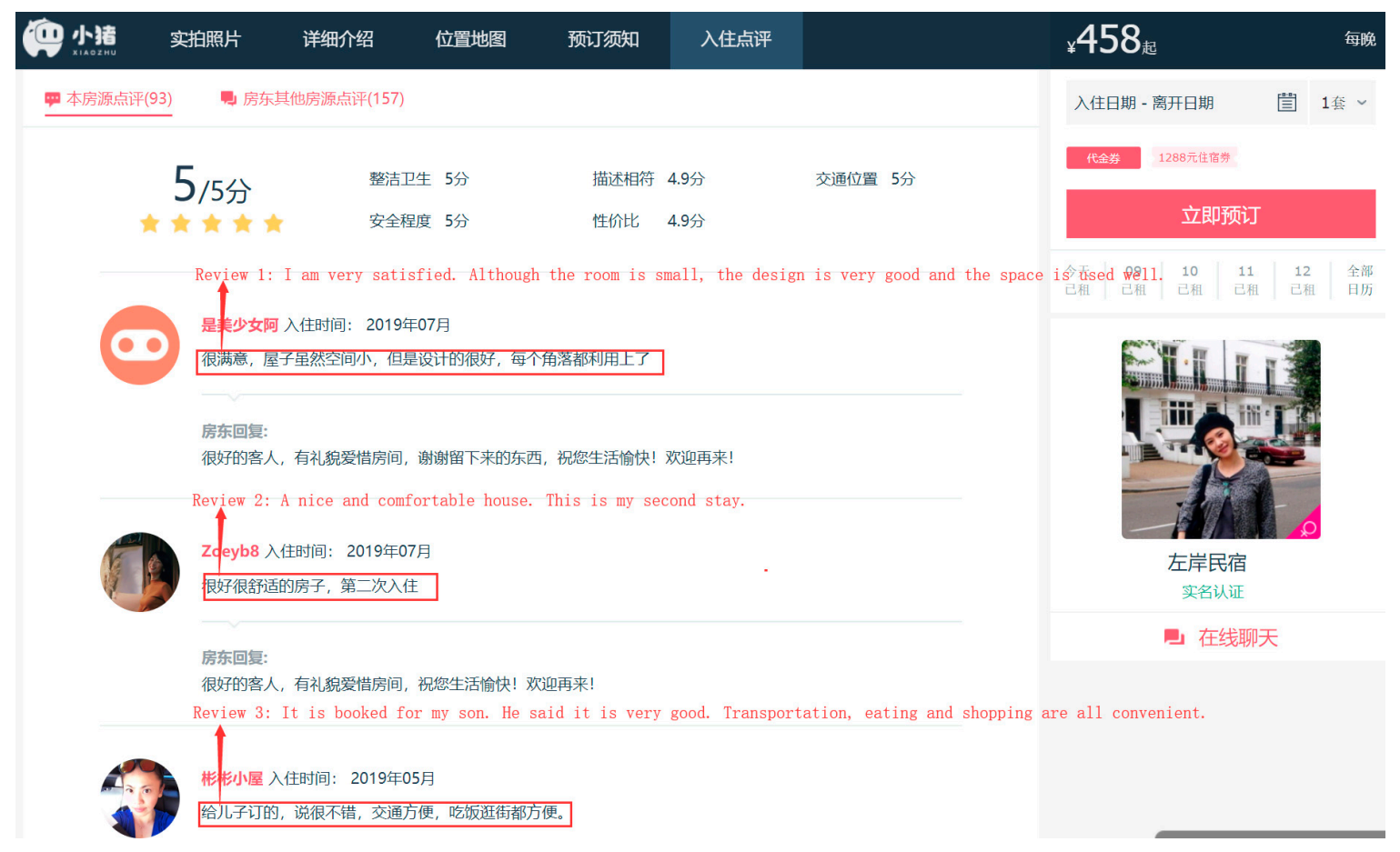

Figure 1. Examples of online review comments in Xiaozhu (source: www.xiaozhu.com).

A Java program was used to crawl the data at the end of 2018. In this study, we took Beijing as the target city to collect samples, because Beijing is the capital of China and attracts a large number of visitors from all parts of the world who shop, travel, and make reservations for accommodations every year. Therefore, the numbers of hosts who would like to rent unoccupied properties, rooms and guests who intend to book short-term accommodations are larger in Beijing than other cities. For example, Sanya, as an international tourist city in China, it owes about 10,000 entire houses and just 500 private rooms in Xiaozhu by the end of 2018 [51]. However, Beijing has held approximately 20,000 entire houses and 7000 private rooms, thereby outranking other cities in China [51]. We spent one week to collect data from 17-25 December 2018. Overall, we obtained a total of 20,571 reviews from entire house guests and 6020 reviews from private room guests.

\subsection{Data Analysis}

Unlike Western languages, no spaces exist between words in a Chinese sentence. Thus, this study adopted the ROST content mining method [52] to identify word frequency in the comments. ROST content mining method is selected because it is a Chinese content mining system developed by Chinese researchers [52]. In addition, it has been widely used in management, sociology, and information science for text processing and statistics $[23,35,52]$. Therefore, ROST CM 6.0 software, which supports custom dictionaries, was used to distinguish and extract high-frequency words and emotional words relevant to this study.

The data analysis process included the following steps. First, we pre-analyzed customer reviews on the Xiaozhu platform and established a custom dictionary, which included "host," "facilities," "location," "decoration," "traffic," "price," and so on. Then, we put unrelated words, such as "I," "and," and "in," into the vocabulary filter and obtained two high-frequency words for "entire house" and "private room." Second, based on the top high-frequency words, we conducted a cluster analysis to identify the key attributes influencing customers' experience. Third, we performed semantic network analysis to obtain the relationship and connection between the words. According to word frequency analysis, semantic network analysis summarizes the connections between these words. It does not care about the vocabulary itself but pays attention to the connection mode and meaning of and between 
words. Finally, we conducted sentiment analysis to identify the guests' emotions and satisfaction. Sentiment analysis is a text mining technique that identifies the emotional bias in consumer reviews, including positive, neutral, and negative emotions, by analyzing people's attitudes towards services or products [53]. This function accurately and truly reflects customers' overall experiences with products and services. We performed sentiment analysis to grasp the emotional expression of Chinese guests regarding different $\mathrm{P} 2 \mathrm{P}$ accommodation products.

\section{Results}

\subsection{Text-Mining Results}

\subsubsection{Text-Mining Results for Entire House Accommodations}

First, we performed word frequency analysis using ROST CM 6.0 software to identify the most frequently used keywords. Table 1 shows the high-frequency keywords for entire house accommodations. It only lists the top 29 high-frequency words due to the rapid fall between the frequency of the 29 th and 30 th terms.

Table 1. Word frequency list for the entire house accommodations (top 29).

\begin{tabular}{cccccc}
\hline Keywords & Frequency & Rank & Keywords & Frequency & Rank \\
\hline host & 7118 & 1 & warm & 1883 & 16 \\
clean & 6507 & 2 & district & 1883 & 17 \\
convenient & 6014 & 3 & sanitation & 1559 & 18 \\
room & 4376 & 4 & comfort & 1523 & 19 \\
location & 4313 & 5 & super & 1472 & 20 \\
subway & 3639 & 6 & facilities & 1394 & 21 \\
house & 3578 & 7 & minute & 1388 & 22 \\
check-in & 3378 & 8 & supermarket & 1338 & 23 \\
transportation & 3016 & 9 & decoration & 1314 & 24 \\
next time & 2840 & 10 & cooking & 1238 & 25 \\
tidy & 2673 & 11 & kitchen & 1201 & 26 \\
hospitality & 2600 & 12 & communication & 1172 & 27 \\
satisfaction & 2090 & 13 & quietness & 1114 & 28 \\
experience & 1979 & 14 & problem & 1129 & 29 \\
environment & 1883 & 15 & & & \\
\hline
\end{tabular}

After identifying the high-frequency words, a review-by-factor matrix was developed, as shown in Table 2. In Table 2, the row refers to a specific review comment and the column represents a specific term. The cell of the matrix is coded as 1 when a specific review comment mentions a particular term (column), and 0 when a specific review comment does not mention a specific term. For instance, the cell of the matrix is coded as 1 because the term "host" is mentioned in Review 1. Instead, the other cell is coded as 0 because "location" is mentioned in Review 1 . 
Table 2. The review-by-factor matrix.

\begin{tabular}{ccccc}
\hline & Host & Location & $\ldots$ & Subway \\
\hline Review 1 & 1 & 0 & $\ldots$ & 0 \\
Review 2 & 0 & 1 & $\ldots$ & 1 \\
Review 3 & 0 & 0 & $\ldots$ & 0 \\
$\ldots$ & & & $\ldots$ & \\
Review 20,571 & 0 & 1 & $\ldots$ & 1 \\
\hline
\end{tabular}

Next, we conducted a hierarchical cluster analysis using SPSS 16.0 to classify the high-frequency words. We did not include irrelevant words, such as "next time" and "super," or generalized words, such as "satisfied," "house," or "experience," in the cluster analysis. Ultimately, we included 21 high-frequency words in the cluster analysis. Figure 2 shows the vertical icicle diagram of the cluster analysis results. Five clusters were identified, including "host service," "facilities," "location and transportation," "cleanliness," and "living environment."

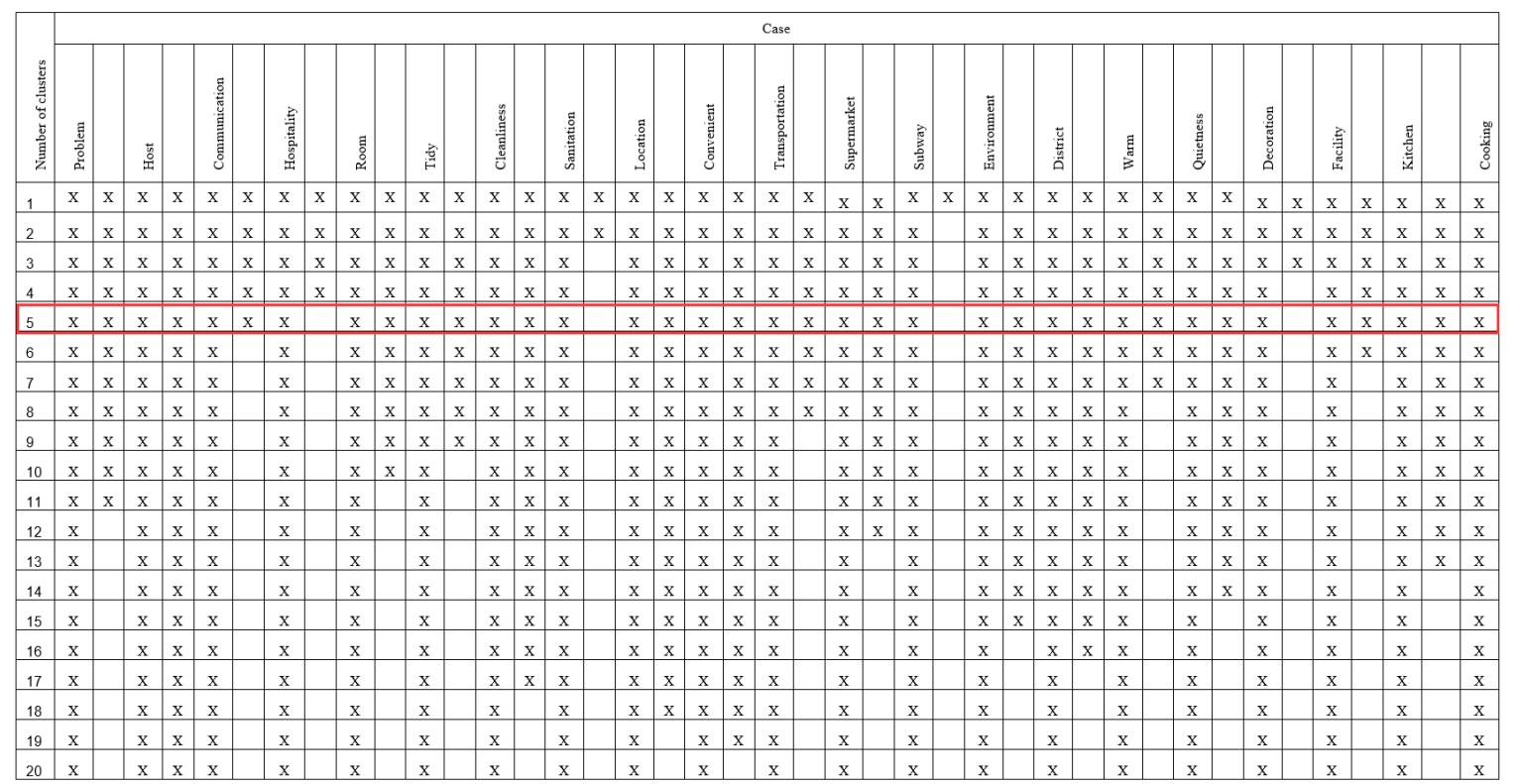

Figure 2. Cluster analysis results for the entire house accommodations.

Using ROST CM 6.0, we conducted a semantic network analysis to further investigate the connections between the high-frequency words. The semantic network analysis results for the reviews of entire houses are illustrated in Figure 3. The nodes and edges linking with the nodes constitute each semantic network. The nodes reflect the words that are frequently mentioned in the review comments. The density of the lines represents the frequency of the co-occurrence. The denser the lines, the more co-occurrences.

Based on the cluster analysis and semantic network analysis results, we categorized the high-frequency words and analyzed the relationships between them. This allowed us to summarize the factors that influence Chinese customers' experience and satisfaction with entire house accommodations. The cluster analysis results shown in Figure 2 indicate five important attributes. 


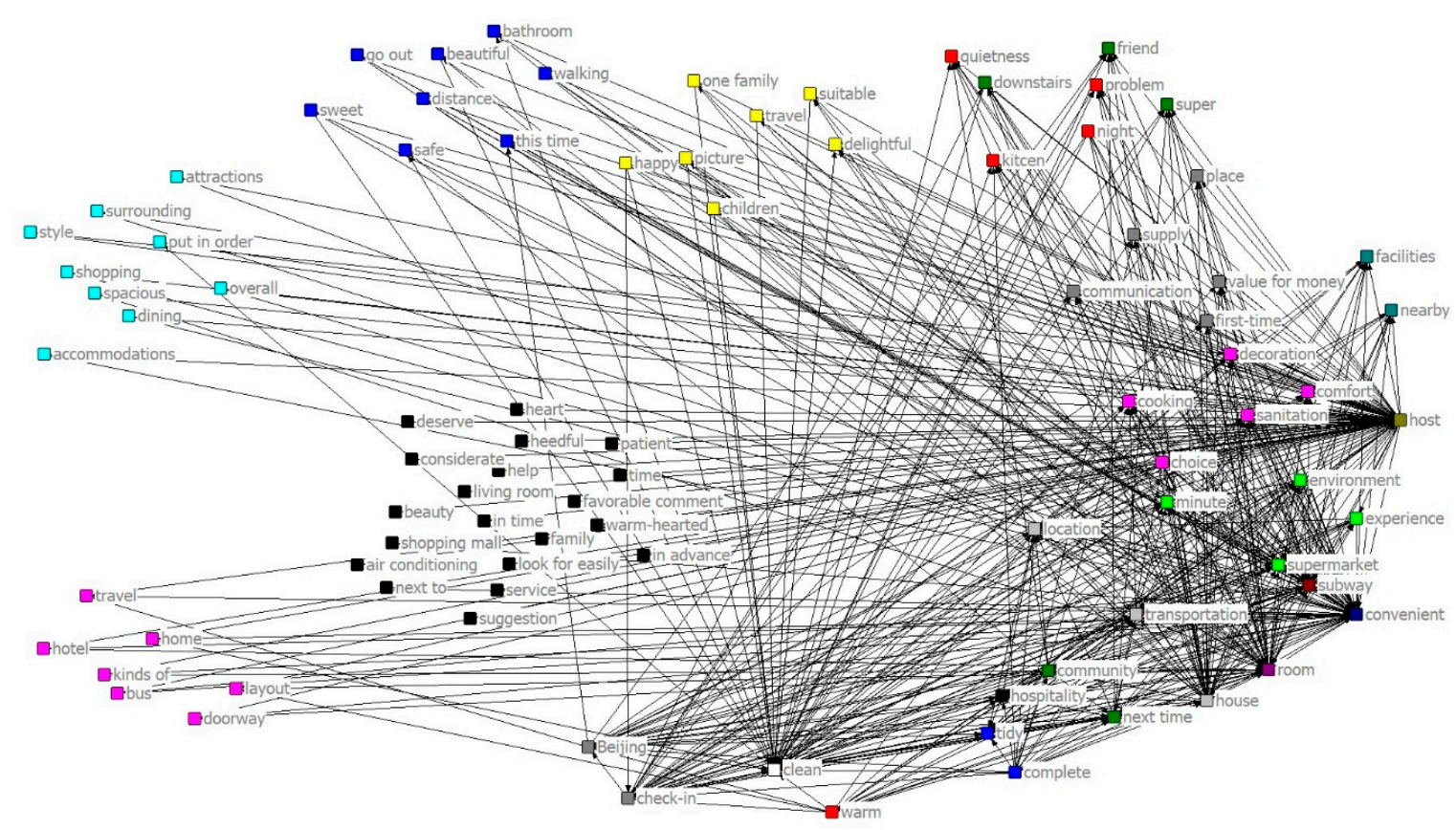

Figure 3. Semantic network results for entire house accommodations.

\section{Host service}

The first attribute identified by the cluster analysis was "host service," which included the words "hospitality," "problem," "communication," and "check-in." The service subject "host" was mentioned frequently (7813 times), followed by "check-in" (3378 times), "hospitality" (2600 times), "communication" (1172 times), and "problem" (1129 times). This indicates that hosts play a key role in customers' experiences with P2P accommodations. Traditional hotels provide standardized staff services from the front desk, doorman, housekeeping, and customer service. This standardized service is in line with hotel norms but lacks a lot of human touches and interactions. In contrast, short-term rental customers communicate with a single person (i.e., the host) in P2P accommodation services. Such services are more affinitive. Thus, Figure 3 shows that the word "host" was often connected with "hospitality," "patience," "thoughtful," and "help." Other frequently mentioned words included "communication," "problem," and "check-in." The reviews show that host-guest communication occurs in different phases (pre, during, and post), for different reasons (check-in/out, and help with problems), and in different ways (face to face and online). To summarize, the services provided by hosts exhibit more care and humanization than the standardized services offered by hotels.

\section{Location and transportation}

The second attribute identified was "location and transportation," which included the words "location," "convenient," "subway," "transportation," "minute," and "supermarket." The word "location" was mentioned 4313 times. This indicates that better locations greatly affect customers' experiences. Figure 3 shows that "transportation," such as "subway" and "minutes on foot," was highly connected with "convenient." This indicates that convenient transportation is important for P2P accommodation experiences. The term "supermarket" was also mentioned frequently, indicating that convenient shopping is also important.

\section{Cleanliness}

The third attribute identified was "cleanliness," which included the words "room," "clean," "tidy," and "sanitation." The word "clean" ranked first (referred to 6407 times). This indicates that cleanliness can give guests good accommodation experiences. This is consistent with the findings of hotel studies that cleanliness plays an important role in affecting consumers' experience and satisfaction [35]. 


\section{Facilities}

The fourth attribute identified was "facilities," which included the words "facilities," "kitchen," and "cooking." The word "facilities" was the most frequently mentioned (1394 times), following by "cooking" (1238 times) and "kitchen" (1201 times). Short-term rental houses cover the basic amenities of a family suite, such as a kitchen, living room, bathroom, and audio-visual equipment with multimedia capabilities. Most of the entire house guests were family members. Among them, "kitchen" and "cooking" were mentioned frequently. Specifically, guests who stay in entire houses are more likely to travel in the form of families or friend groups. Thus, they prefer cooking by themselves, which makes them feel more at home. A typical comment was, "A family of five lives more comfortably than in a hotel. Cooking for yourself and eating is also clean and comfortable."

\section{Living environment}

The fifth attribute identified was "living environment," which included the words "environment," "warm," "district," "decoration," "comfort," and "quietness." It can be divided into outside environment and indoor environment. Figure 3 shows that the word "warm" was highly connected with "district" and "environment." It was also connected with "home" and "layout." This indicates that P2P accommodations give people a sense of warmth and create a "home-away-from-home" feeling. This is a special experience for guests that traditional standardized hotels cannot provide. In terms of the surrounding environment, the quietness of the district was often mentioned. Figure 3 also shows that the words "district," "home," and "warm" were closely related to words describing the customers' intention to still choose to live in this accommodation (i.e., "next time" and "satisfied").

\subsubsection{Text-Mining Results for Private Room Accommodations}

We also conducted a high-frequency word analysis and a hierarchy-cluster analysis for the private room reviews. Table 3 presents the top 30 high-frequency keywords and Figure 4 shows the cluster analysis results. Six clusters were identified, including "host service," "location and transportation," "security and privacy," "facilities," "cleanliness," "value for money," and "living environment."

To further understand the connections and meanings among the high-frequency words, we conducted a semantic network analysis for the private room reviews. Figure 5 shows the semantic network results.

Table 3. Word frequency list for the private room accommodations (top 30).

\begin{tabular}{cccccc}
\hline Keywords & Frequency & Rank & Keywords & Frequency & Rank \\
\hline host & 1897 & 1 & aunt & 404 & 16 \\
clean & 1489 & 2 & warm & 398 & 17 \\
convenient & 1409 & 3 & district & 390 & 18 \\
room & 1020 & 4 & quiet & 386 & 19 \\
subway & 722 & 5 & sanitation & 356 & 20 \\
location & 716 & 6 & place & 323 & 21 \\
check-in & 702 & 7 & comfort & 320 & 22 \\
transportation & 683 & 8 & super & 294 & 23 \\
hospitality & 675 & 9 & home & 286 & 24 \\
tidy & 580 & 10 & safe & 284 & 25 \\
value for money & 557 & 11 & satisfied & 256 & 26 \\
house & 536 & 12 & minute & 232 & 27 \\
next time & 519 & 13 & facilities & 228 & 28 \\
environment & 479 & 14 & supermarket & 210 & 29 \\
experience & 468 & 15 & night & 188 & 30 \\
\hline
\end{tabular}




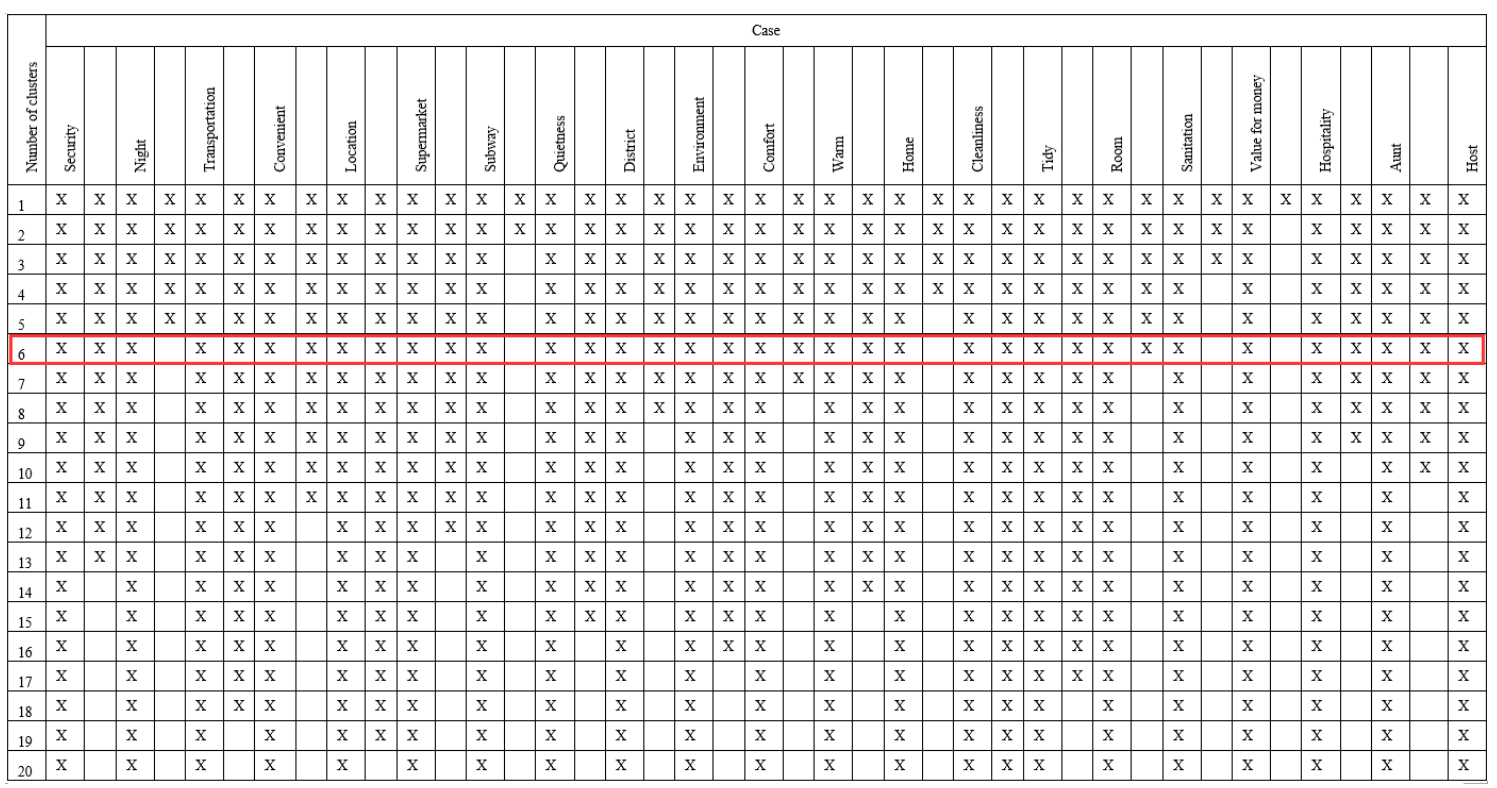

Figure 4. Cluster analysis results for the private room accommodations.

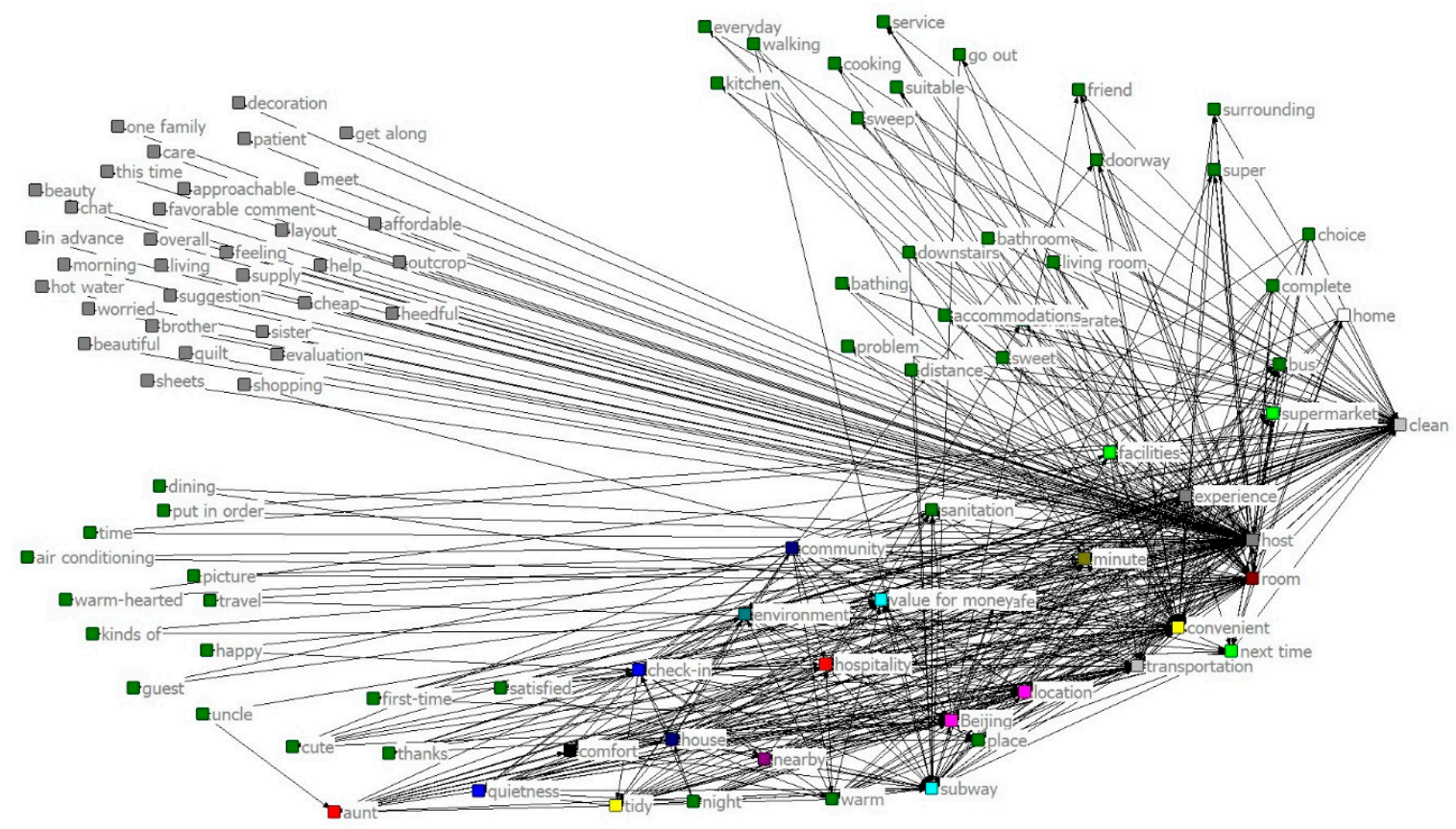

Figure 5. Semantic network results for private room accommodations.

To better understand the customers' private room accommodation experiences, we summarize the analysis results in detail as follows. Specifically, the cluster analysis results shown in Figure 4 indicate six important attributes.

\section{Host service}

The first attribute identified was "host service." This attribute covered a variety of concepts, such as "hospitality," "check-in," and "aunt." The word "host" was mentioned frequently (1897 times) across 6020 reviews, indicating that hosts play a key role in private room customers' experiences. Figure 5 shows that the word "host" was always connected with familiar titles, such as "aunt," "sister," "uncle," and "brother." This indicates that the host-guest relationship is closer for private room accommodations. 
Moreover, "host" was always connected with words such as "chat," "care," and "get along." This indicates that host-guest interaction is more frequent for private room accommodations.

2. Location and transportation

The second attribute identified was "location and transportation." The same as for entire house accommodations, the customers who stayed in private rooms also paid attention to the location and transportation close to the house. The words "subway," "location," "transportation," "supermarket," and "minute" were mentioned frequently.

\section{Cleanliness}

The third attribute identified was "cleanliness," including the words "clean," "sanitation," "tidy," and "room." The word "bathroom" was also mentioned frequently (148 times). This may because the bathroom is a public area in private room accommodations, leading to many negative comments about the shared space.

\section{Value for money}

The fourth attribute identified was "value for money," which appeared frequently in the reviews (557 times). As shown in Table 2, it ranked 10th among the 30 high-frequency keywords. This indicates that private room guests pay great attention to the cost performance of P2P accommodations. The core advantage of a private room is its low price, which attracts guests, especially those who travel alone. When "value for money" appeared in the reviews, customers were always comparing private rooms with hotels. Relevant customer comments included, "I recommend P2P accommodations; they are more affordable than hotels. Compared with some geographically superior hotels, the value of a private room is super high." Such evidence indicates that "value for money" is an important attribute affecting visitors' decision to choose private room accommodations.

\section{Security and privacy}

The fifth attribute influencing the private room customers' experiences was "security and privacy," including the words "safe" and "night." The word "safe" was mentioned frequently (284 times) for private room accommodations. This may be because customers often experience private room accommodations alone and have to share the house with the landlord or other customers. Female guests who choose P2P accommodations for the first time may particularly have various safety and privacy concerns. Related comments included, "Concerning the security, the host changes the coded lock for each guest" and "There was a small issue that I want to mention: I lived with a male host. Every time I saw him, he was shirtless ... Well, because I am a girl, I felt a little bit uncomfortable." Interestingly, we also found that most of the female guests who mentioned security were more inclined to choose female hosts, with the words "sister" and "aunt" appearing in their reviews. The risk of encountering a safety problem is lower when living with a female host than with a male host.

The semantic network diagram in Figure 5 shows that the word "safety" was highly related with "district." Thus, private room guests also pay attention to the safety of the community environment. Typical comments included, "The community is an upscale district, clean and safe." Hosts also worried about whether their guests were safe, especially those traveling alone. Typical comments included, "The host was very kind and was very concerned about my safety outside."

\section{Living environment}

The same as for entire house accommodations, "living environment" was also a key attribute affecting private room guests' experience, including the outside and inside environments. The words "district," "environment," "quietness," "home," and "warm" were mentioned frequently. 


\subsection{Sentiment Analysis Results}

Using sentiment analysis in ROST CM 6.0, we further analyzed the emotions expressed in P2P accommodation reviews. Emotional words are defined by CNKINet, which includes positive emotional words, such as "satisfaction," "hospitality," "happy," "great," "warm," and "comfortable," and negative emotional words, such as "noisy," "bad," "stressful," "sorry," and "insufficient." Tussyadiah et al. [13] suggested that negative reviews of $\mathrm{P} 2 \mathrm{P}$ accommodations must be analyzed to provide hosts with guidelines for improvement. Thus, we focused on P2P accommodation guests' negative sentiments regarding specific nouns, such as "host," "room," and "cleanliness."

Table 4 presents the negative sentiment analysis results. In general, both the customers who stayed in entire houses and private rooms exhibited fewer negative than positive emotions. In the following section, we analyze short-term rental guests' negative sentiments in detail.

Table 4. Comparison of the negative sentiments between the entire house and private room accommodations.

\begin{tabular}{cccc}
\hline \multirow{2}{*}{ Attributes } & Keywords & \multicolumn{2}{c}{ Proportion of Negative Reviews (\%) } \\
\cline { 2 - 4 } & & Entire House & Private Room \\
\hline \multirow{2}{*}{ Cleanliness } & sanitation & $10.12 \%$ & $13.20 \%$ \\
& bathroom & $18.44 \%$ & $32.43 \%$ \\
& room & $6.19 \%$ & $14.56 \%$ \\
\hline Host service & host & $7.55 \%$ & $5.87 \%$ \\
& service & $5.90 \%$ & $3.49 \%$ \\
& aunt & $1.63 \%$ & $0.69 \%$ \\
Location and & communication & $2.73 \%$ & $1.10 \%$ \\
transportation & location & $13.72 \%$ & $8.20 \%$ \\
& transportation & $8.72 \%$ & $5.98 \%$ \\
& subway & $4.50 \%$ & $2.56 \%$ \\
& supermarket & $2.28 \%$ & $1.12 \%$ \\
\hline \multirow{2}{*}{ Living environment } & bus & $2.50 \%$ & $0.89 \%$ \\
\hline Security and privacy & decoration & $0.78 \%$ & $2.23 \%$ \\
& layout & $0.65 \%$ & $1.03 \%$ \\
\hline Falue for money & environment & $2.82 \%$ & $5.26 \%$ \\
\hline \multirow{2}{*}{ Facilities } & district & $0.67 \%$ & $0.56 \%$ \\
\hline
\end{tabular}

1. Cleanliness

As shown in Table 5, for both entire houses and private rooms, the attribute with the most negative comments was "cleanliness," especially the cleanliness of the bathroom. This finding indicates that P2P providers should pay more attention to aspects of cleanliness. Examples of the negative reviews are presented below.

Negative reviews

"The space is really unacceptable. The quilt is musty and the house is old. The bathroom is completely leaky and the outside is wet. This experience was bad." -Entire house guests

"The sanitary conditions are very unsatisfactory and there are bugs in the bathroom and kitchen. The quilt also smells." - Entire house guests 


\section{Host service}

Interestingly, the guests who stayed in private rooms left a lower proportion of negative reviews of "host service" (referring to "host," "service," "aunt," and "communication") than those who stayed in entire houses. This finding reveals that more social interaction with the host may increase customer satisfaction in P2P accommodations.

In addition, $\mathrm{P} 2 \mathrm{P}$ accommodations provide more flexible services than hotels, such as late check-out. However, the lack of standardized service in such accommodations may be problematic. Relevant comments included, "The appointment with the host to check out was at 11:00. His parents arrived at 10:00 and did not knock on the door. They came straight into the house. We heard that someone had come in and suddenly woke up, quite unhappily, and had to rush to tidy up and leave at 10:50. I just hope that the host can learn from this situation and make improvements for the next guest." Thus, P2P platform providers should think about how to guarantee basic service quality while maintaining flexible services.

\section{Living environment}

The guests who stayed in private rooms left a higher proportion of negative reviews of "living environment" (5.26\%) than those who stayed in entire houses $(2.82 \%)$. The customers also left positive or negative reviews based on whether the actual environment was better or worse than the pictures posted online. This finding indicates that hosts should attach importance to the pictures they post online and provide real pictures so consumers have reasonable expectations. Examples of the positive and negative reviews are presented below.

Positive review

"The room is very neat and beautiful, the decoration style is consistent with the pictures, the interior is very beautiful." —Entire house guests

Negative review

"Despite the decoration and lighting in the photo, the actual decoration is actually relatively minimal and the facilities are very basic." - Entire house guests

\section{Facilities}

The guests who stayed in private rooms left more negative reviews of facilities $(10.78 \%)$, such as the bed, bathroom, and towels, than those who stayed in entire houses. However, the guests who stayed in entire houses left more negative reviews of the kitchen $(17.40 \%)$ than those who stayed in private rooms $(3.72 \%)$. This may be because private room customers often travel alone and do not care as much about the aspects of the kitchen. Examples of the negative reviews are presented below.

Negative reviews

"The equipment of the house needs to be updated. For example, the washing machine leaks water when turned on, the range hood is loud, and the bathroom does not have a fan." -Entire house guests

“The kitchen is really a mess!" —Entire house guests 
Table 5. Similarities and differences between the attributes for the entire house and private room accommodations.

\begin{tabular}{|c|c|c|c|c|c|c|c|}
\hline & Host Service & Facilities & $\begin{array}{l}\text { Location and } \\
\text { Transportation }\end{array}$ & Value for Money & $\begin{array}{l}\text { Security and } \\
\text { Privacy }\end{array}$ & Cleanliness & Living Environment \\
\hline Entire house & $\begin{array}{l}\text { - Hospitality of } \\
\text { the host } \\
\text { - Communication and } \\
\text { problem solving } \\
\text { before arrival and } \\
\text { during the stay } \\
\text { - Convenient check-in }\end{array}$ & $\begin{array}{l}\text { - High emphasis } \\
\text { on the facilities } \\
\text { of the space, } \\
\text { especially the } \\
\text { aspects of } \\
\text { the kitchen }\end{array}$ & $\begin{array}{l}\text { - The location of the } \\
\text { house from } \\
\text { supermarkets, shops, } \\
\text { and restaurants } \\
\text { Transportation, such } \\
\text { as the subway and } \\
\text { bus stations, are } \\
\text { minutes away } \\
\text { on foot }\end{array}$ & $\begin{array}{l}\text { Low emphasis on } \\
\text { value for money } \\
\text { (ranked 36th) }\end{array}$ & $\begin{array}{l}\text { Low concerns } \\
\text { regarding } \\
\text { safety } \\
\text { and privacy }\end{array}$ & $\begin{array}{l}\text { Cleanliness } \\
\text { of the rooms } \\
\text { and bathrooms }\end{array}$ & $\begin{array}{l}\text { - } \quad \text { Outside environment } \\
\text { Indoor environment, } \\
\text { such as good } \\
\text { decoration, layout, } \\
\text { and warmth as well as } \\
\text { feeling at home }\end{array}$ \\
\hline Private room & 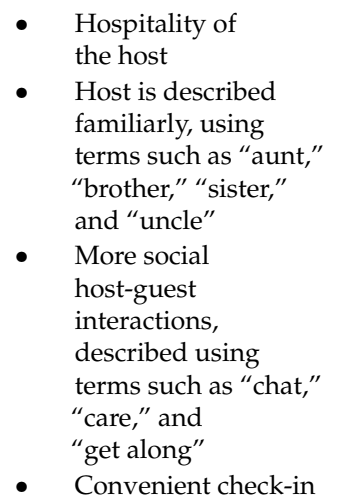 & $\begin{array}{l}\text { - Low emphasis } \\
\text { on the facilities }\end{array}$ & $\begin{array}{l}\text { - The same as } \\
\text { entire house }\end{array}$ & $\begin{array}{l}\text { High emphasis } \\
\text { on value for } \\
\text { money } \\
\text { (ranked 11th) }\end{array}$ & $\begin{array}{l}\text { - High concerns } \\
\text { regarding } \\
\text { safety outside } \\
\text { at night } \\
\text { - High concerns } \\
\text { regarding } \\
\text { privacy in the } \\
\text { house, } \\
\text { especially in } \\
\text { common areas }\end{array}$ & $\begin{array}{l}\text { - The same as } \\
\text { entire house }\end{array}$ & $\begin{array}{l}\text { - The same as } \\
\text { entire house }\end{array}$ \\
\hline
\end{tabular}




\section{Security and privacy}

As shown in Table 5, the guests who stayed in private rooms left more negative reviews of "security and privacy" (4.57\%) than those who stayed in entire houses $(2.47 \%)$. This may be because private room customers have to share the house with the landlord or other customers. Examples of the negative reviews are presented below.

Negative reviews

"When coming back at night, there are few street lights, which is not very safe." —Private room guest

“The toilet doors don't work very well, so I always felt unsafe." —Private room guest

"It is inconvenient for men and women to live together. The bathroom has no lock at all and can be opened with a light pull. And there is a big gap on the side of the door, which is very clear from the side." —Private room guest

"The room is cut off, which is somewhat inconvenient. Hope that the host can block the window of the bathroom to help guests avoid embarrassment." —Private room guest

\section{Location and transportation}

Interestingly, the guests who stayed in private rooms left fewer negative reviews of "location and transportation" than those who stayed in entire houses. The reason may be that the low price of a private room makes inconvenient location and transportation tolerable. In contrast, entire house guests pay higher prices and thus have higher expectations. Examples of the negative reviews are presented below.

Negative reviews

"The only regret is that it is a little far from the subway. The children had to walk for 20 min."

-Entire house guests

"The location is a bit biased and far from the sights." —Private room guest

\section{Value for money}

In general, P2P accommodations have higher "value for money" than hotels. Thus, fewer negative reviews of "value for money" were left by both those who stayed in entire houses $(3.87 \%)$ and private rooms $(0.39 \%)$. An example of the negative reviews is presented below.

Negative review

"It is not good value for the money. It is a little expensive, but the facilities and equipment are old." —Entire house guests

\section{Discussion and Implications}

\subsection{Discussion}

We find that the Chinese guests who stayed in both entire houses and private rooms cared about "host service," "location and transportation," "cleanliness," and "living environment." This is line with the findings of previous studies $[9,13,38]$, which have also emphasized the importance of "host," "location," and "facilities and atmosphere" in P2P accommodations. In addition, the private room customers cared more about the "value for money" and "security and privacy," whereas the entire house customers cared more about "facilities," with a particular focus on the aspects of the "kitchen." Table 5 presents the similarities and differences between the attributes of guests' experiences with entire house and private room accommodations. 
First, the guests who stayed in private rooms and entire houses used different words to describe the hosts. Specifically, the private room guests used "beauty," "brother," "sister," "aunt," and "uncle." Of these words, the entire house guests used only "beauty." In addition, the word "host" was usually connected with "chat," "care," and "get along" for private room guests, indicating that they were more open to social interaction with hosts than the guests who stayed in entire houses. This may be because guests staying in private rooms usually live with their hosts, thereby leading to more social interaction and closer relationships with them. In this case, the host-guest relationship changes from a transactional relationship to a friendship. For the guests who stayed in entire houses, host-guest communication mostly referred to help with some problems, such as check-in, without real social interaction. This explains why some studies have emphasized host-guest interaction as a key attribute $[10,13]$, whereas others have proposed that the host is more like a facilitator than a friend.

Second, in general, both the entire house and private room guests cared about the security of P2P accommodations. For example, both cared about the "password lock" and "safety of the district." This may be because interpersonal trust is low in China and guests pay higher attention to safety considerations. The term "safety" was mentioned more frequently and ranked higher by guests who stayed in private rooms than by those who stayed in entire houses. In addition, due to sharing a house with the host or other guests, the guests who stayed in private rooms paid more attention to the privacy within the house. Relevant comments included, "It was too hot and the host wore shorts and was shirtless while sitting in the living room. When women entered and exit the gates and toilets, it was always a little bit awkward." This scenario does not occur for customers who stay in entire houses. The penetration rate of $\mathrm{P} 2 \mathrm{P}$ accommodations is only $2 \%$ in China, compared to $25 \%$ in the U.S.A. One reason may be people's concerns regarding safety and their distrust for P2P accommodations.

Third, the term "value for money" was mentioned more frequently by the guests who stayed in private rooms (ranked 11th) than by those who stayed in entire houses (ranked 36th). This finding indicates that customers who choose to rent private rooms focus on the lower price.

Finally, the entire house customers put more emphasis on "facilities," with a particular focus on the aspects of the "kitchen." Chinese guests who are influenced by several-thousand-year-old Jia cultural traditions may prefer cooking for themselves and enjoy staying in a comfortable space as a group when traveling. The guests who stayed in private rooms paid less attention to the "kitchen." This may be because most guests who rent private rooms travel alone.

\subsection{Theoretical Implications}

In theory, this study contributes to the studies relating to the hotels and sharing economy by a better understanding of Chinese customers' experience and satisfaction with P2P accommodations. Although previous studies have provided some evidence of customers' experience with P2P accommodations $[9,13,14,25,38]$, they have mainly focused on customers in Western countries, such as Europe and the U.S.A. Cheng and Jin [9] suggested that Western users and Asian users must be distinguished, as context, such as the general multiculturality and safety of an environment, can influence the salient attributes of $\mathrm{P} 2 \mathrm{P}$ accommodation experiences. We extend previous studies $[9,38]$ by investigating the key attributes influencing Chinese customers' experience and satisfaction with short-term rentals.

Specifically, first, despite other studies identifying some attributes, such as "host," "location," and "facilities and amenities" [9,13], they are limited in their focus on guests in Western countries. This study contributes to these studies by suggesting that Chinese guests, especially those who stay in private rooms, place great value on "security and privacy," in addition to above attributes.

Second, we explain why the attributes of guests' experiences with P2P accommodations are debated. Specifically, we argue that customers of entire houses and private rooms have different experiences and attitudes toward short-term rental accommodations. First, the results suggest that guests who stay in private rooms are more open to social interaction with hosts, whereas the host is more like a facilitator than a friend for guests of entire houses. This study complements others $[9,10,13]$ 
by explaining the different ideas on the role that host-guest interaction plays in P2P accommodations. The sentiment analysis suggests that guests who stay in private rooms leave a lower proportion of negative reviews of "host service" than guests of entire houses. This indicates that more host-guest interactions may increase customer satisfaction with short-term rentals. Thus, we also contribute to the hotel literature $[35,54,55]$ by emphasizing the role of social interaction in improving customer satisfaction in the hospitality industry.

Finally, although studies have identified the importance of "value for money" in P2P accommodations, different ideas exist $[9,10,56]$. We extend these studies by suggesting that private room guests value "value for money" more than entire house guests.

\subsection{Practical Implications}

We identify the attributes that influence Chinese customers' experience and satisfaction with P2P accommodations and compare the experiences of guests staying in entire houses and private rooms. In practice, the findings of this study can provide guidelines to help short-term rental providers better highlight their service attributes to improve their service and gain a competitive advantage.

First, the most critical attribute is "host service," which includes the host's hospitality, service, and communication and affects Chinese guests' experience and satisfaction. Thus, we suggest that hosts should always be friendly, provide warm service, and show concern for their guests' problems. Hosts can also provide a pick-up service to improve service levels. The results suggest that guests who stay in private rooms have more social interaction with their hosts, such as through the use of the words "chat," "care," and "dining with hosts." The sentiment analyses suggest that guests who stay in private rooms leave a lower proportion of negative reviews of "host service" than guests who stay in entire houses. This indicates that more social interaction may increase customer satisfaction. Thus, hosts who provide private room rentals should demonstrate appropriate emotional expressions and maintain positive host-guest interactions, so that their guests can feel the care of "home" and to ultimately achieve high customer satisfaction. Hosts of entire houses are encouraged to realize the importance of social interaction, demonstrate care for their guests' needs, and solve their guests' problems positively to achieve higher customer satisfaction. This finding also suggests that hotel managers should prioritize personal interactions with hotel guests.

Second, Chinese guests who stay in private rooms highly value "security and privacy." Thus, it is necessary to avoid and prevent uncomfortable, embarrassing, and even dangerous situations. For example, private rooms should be equipped with independent door locks with intelligent fingerprint recognition to improve safety. For Chinese guests' security concerns, P2P accommodation platforms should also improve safety mechanisms. For example, they may recommend using a "one-button call for 110" function or provide a credit evaluation mechanism, thus increasing customers' sense of security.

Third, for entire house accommodations, hosts are encouraged to improve the facilities, amenities, decoration, and layout of their spaces, paying particular attention to whether the kitchen is clean and complete. Guests who stay in entire houses mostly travel in families or with friends. They tend to prefer cooking for themselves and enjoy staying in a comfortable space as a group when traveling. In addition, entire house guests don't pay much attention to price. Thus, we suggest that entire house hosts can raise house price appropriately to increase their revenues, while providing high quality amenities and service excellence.

Finally, both entire room and private room guests pay attention to the cleanliness of their P2P accommodations. The ratio of negative reviews of "cleanliness" these guests leave is high. Cleanliness is commonly guaranteed in hotels. Thus, service providers should improve sanitary conditions and the Xiaozhu platform should consider how hosts can ensure service quality while providing personalized and flexible services. 


\section{Conclusions and Limitations}

This study has investigated the salient attributes that influence Chinese visitors' experiences by analyzing online reviews from Xiaozhu platform. We propose that guests who stayed in entire houses and those who stayed in private rooms experience short-term rentals differently. By analyzing a total of 20,571 reviews from entire house guests and 6020 reviews from private room guests, five attributes were identified for entire houses and six attributes were identified for private rooms. Based on the results, we have discussed similarities and differences between the two types of P2P accommodations and presented a number of important implications for the literature and for hosts of short-term rental accommodations.

This study also has some limitations. First, we conducted this study in China. Other developing countries should be included in future studies to generalize the findings. Second, other statistical analysis method, such as regression analysis, can be combined to deepen the depth of the research by integrating other variables (e.g., ratings and host attributes). Finally, the guests who provide review comments online may not represent other customers with no feedback. Future studies should extend the samples, especially those who never lived in P2P accommodations, to grangerize the findings and provide more insights.

Author Contributions: Conceptualization, Y.G. and C.W.; methodology, Y.W.; software, Y.W.; formal analysis, Y.G. and Y.W.; investigation, C.W.; resources, Y.G.; data curation, Y.W.; writing—original draft preparation, Y.G. and C.W.; writing - review and editing, Y.G. and C.W.; visualization, Y.W. and C.W.; supervision, Y.G. and C.W.; project administration, Y.G.; funding acquisition, Y.G. and C.W.

Funding: This research was funded by the National Natural Science Foundation of China, grant number \#71701034; MOE (Ministry of Education of China), grant number \#19YJC630048; Fundamental Research Funds for the Central Universities of China (Dalian Maritime University), grant number \#20110117203; Program Innovative Research Team in University of Ministry of Education of China, grant number \#IRT_17R13, and Social Science Planning Foundation of Liaoning Province: L18BGL037.

Conflicts of Interest: The authors declare no conflict of interest.

\section{References}

1. Hamari, J.; Sjöklint, M.; Ukkonen, A. The Sharing Economy: Why People Participate in Collaborative Consumption. J. Assoc. Inf. Sci. Technol. 2016, 67, 2047-2059. [CrossRef]

2. Belk, R. You are What You Can Access: Sharing and Collaborative Consumption Online. J. Bus. Res. 2014, 67, 1595-1600. [CrossRef]

3. Botsman, R.; Rogers, R. What's Mine Is Yours: How Collaborative Consumption is Changing the Way We Live; Collins London: London, UK, 2011.

4. Jefferson-Jones, J. Can Short-Term Rental Arrangements Increase Home Values? A Case for Airbnb and Other Home Sharing Arrangements. Cornell Real Estate Rev. 2015, 13, 11-19.

5. Airbnb. Airbnb Summer Travel Report: 2015. Available online: https://blog.atairbnb.com/wp-content/ uploads/2015/09/Airbnb-Summer-Travel-Report-1.pdf (accessed on 5 August 2019).

6. Marquis, C.; Yang, Z. The Sharing Economy in China: Toward a Unique Local Model. China Policy Rev. 2014, 9, 109-111.

7. Yannopoulou, N.; Moufahim, M.; Bian, X. User-Generated Brands and Social Media: Couchsurfing and AirBnb. Contemp. Manag. Res. 2013, 9, 85-90. [CrossRef]

8. Bridges, J.; Vásquez, C. If Nearly All Airbnb Reviews Are Positive, Does that Make them Meaningless? Curr. Issues Tour. 2018, 21, 1-19. [CrossRef]

9. Cheng, M.; Jin, X. What Do Airbnb Users Care About? An Analysis of Online Review Comments. Int. J. Hosp. Manag. 2019, 76, 58-70. [CrossRef]

10. Festila, M.; Müller, S. The Impact of Technology-Mediated Consumption on Identity: The Case of Airbnb. In Proceedings of the 50th Hawaii International Conference on System Sciences, Hilton Waikoloa Village, HI, USA, 4-7 January 2017.

11. Guttentag, D. Airbnb: Disruptive Innovation and the Rise of an Informal Tourism Accommodation Sector. Curr. Issues Tour. 2015, 18, 1192-1217. [CrossRef] 
12. Guttentag, D.; Smith, S.; Potwarka, L.; Havitz, M. Why Tourists Choose Airbnb: A Motivation-Based Segmentation Study. J. Travel Res. 2018, 57, 342-359. [CrossRef]

13. Tussyadiah, I.P.; Tussyadiah, I.P.; Zach, F. Identifying Salient Attributes of Peer-To-Peer Accommodation Experience. J. Travel Tour. Mark. 2017, 34, 636-652. [CrossRef]

14. Farmaki, A.; Stergiou, D.P. Escaping Loneliness through Airbnb Host-Guest Interactions. Tour. Manag. 2019, 74, 331-333. [CrossRef]

15. Penz, E.; Hartl, B.; Hofmann, E. Collectively Building a Sustainable Sharing Economy Based on Trust and Regulation. Sustainability 2018, 10, 3754. [CrossRef]

16. Agag, G.; Eid, R. Examining the Antecedents and Consequences of Trust in the Context of Peer-To-Peer Accommodation. Int. J. Hosp. Manag. 2019, 81, 180-192. [CrossRef]

17. Ert, E.; Fleischer, A.; Magen, N. Trust and Reputation in the Sharing Economy: The Role of Personal Photos in Airbnb. Tour. Manag. 2016, 55, 62-73. [CrossRef]

18. Hawlitschek, F.; Teubner, T.; Adam, M.T.P.; Borchers, N.S.; Moehlmann, M.; Weinhardt, C. Trust in the Sharing Economy: An Experimental Framework. In Proceedings of the 37th International Conference on Information Systems, Dublin, Ireland, 11-14 December 2016.

19. Malazizi, N.; Alipour, H.; Olya, H. Risk Perceptions of Airbnb Hosts: Evidence from a Mediterranean Island. Sustainability 2018, 10, 1349. [CrossRef]

20. Prayag, G.; Ozanne, L.K. A Systematic Review of Peer-To-Peer (P2P) Accommodation Sharing Research from 2010 to 2016: Progress and Prospects from the Multi-Level Perspective. J. Hosp. Market. Manag. 2018, 27, 649-678. [CrossRef]

21. Sthapit, E.; Björk, P. Sources of Distrust: Airbnb Guests' Perspectives. Tour. Manag. Perspect. 2019, 31, $245-253$. [CrossRef]

22. Wu, J.; Zeng, M.; Xie, K.L. Chinese Travelers' Behavioral Intentions Toward Room-Sharing Platforms. Int. J. Contemp. Hosp. Manag. 2017, 29, 2688-2707. [CrossRef]

23. Zhang, H.; Rao, H.; Feng, J. Product Innovation Based on Online Review Data Mining: A Case Study of Huawei Phones. Electron. Commer. Res. 2018, 18, 3-22. [CrossRef]

24. Wu, X.; Shen, J. A Study on Airbnb'S Trust Mechanism and the Effects of Cultural Values-Based on a Survey of Chinese Consumers. Sustainability 2018, 10, 3041. [CrossRef]

25. Belarmino, A.; Whalen, E.; Koh, Y.; Bowen, J.T. Comparing Guests' Key Attributes of Peer-To-Peer Accommodations and Hotels: Mixed-Methods Approach. Curr. Issues Tour. 2019, 22, 1-7. [CrossRef]

26. Liang, L.J.; Choi, H.C.; Joppe, M. Exploring the Relationship Between Satisfaction, Trust and Switching Intention, Repurchase Intention in the Context of Airbnb. Int. J. Hosp. Manag. 2018, 69, 41-48. [CrossRef]

27. Tussyadiah, I.P. Factors of Satisfaction and Intention to Use Peer-To-Peer Accommodation. Int. J. Hosp. Manag. 2016, 55, 70-80. [CrossRef]

28. Callan, R.J.; Bowman, L. Selecting a Hotel and Determining Salient Quality Attributes: A Preliminary Study of Mature British Travellers. Int. J. Tour. Res. 2000, 2, 97-118. [CrossRef]

29. Alcántara-Alcover, E.; Artacho-Ramírez, M.Á.; Martínez-Guillamón, N.; Campos-Soriano, N. Purpose of Stay and Willingness to Stay as Dimensions to Identify and Evaluate Hotel Experiences. Int. J. Hosp. Manag. 2013, 33, 357-365. [CrossRef]

30. Albayrak, T.; Caber, M. Prioritisation of the Hotel Attributes According to their Influence on Satisfaction: A Comparison of Two Techniques. Tour. Manag. 2015, 46, 43-50. [CrossRef]

31. Ariffin, A.A.M.; Maghzi, A. A Preliminary Study on Customer Expectations of Hotel Hospitality: Influences of Personal and Hotel Factors. Int. J. Hosp. Manag. 2012, 31, 191-198. [CrossRef]

32. Verma, R. Customer Choice Modeling in Hospitality Services: A Review of Past Research and Discussion of some New Applications. Cornell Hosp. Q. 2010, 51, 470-478. [CrossRef]

33. Dolnicar, S.; Otter, T. Which Hotel Attributes Matter? A Review of Previous and a Framework for Future Research. Fac. Commer. Pap. 2003, 1, 268.

34. Crnojevac, I.H.; Gugić, J.; Karlovčan, S. ETourism: A Comparison of Online and Offline Bookings and the Importance of Hotel Attributes. J. Inf. Organ. Sci. 2010, 34, 41-54.

35. Li, H.; Ye, Q.; Law, R. Determinants of Customer Satisfaction in the Hotel Industry: An Application of Online Review Analysis. Asia Pac. J. Tour. Res. 2013, 18, 784-802. [CrossRef]

36. Cheng, M. Sharing Economy: A Review and Agenda for Future Research. Int. J. Hosp. Manag. 2016, 57, 60-70. [CrossRef] 
37. Zervas, G.; Proserpio, D.; Byers, J.W. The Rise of the Sharing Economy: Estimating the Impact of Airbnb On the Hotel Industry. J. Mark. Res. 2017, 54, 687-705. [CrossRef]

38. Camilleri, J.; Neuhofer, B. Value Co-Creation and Co-Destruction in the Airbnb Sharing Economy. Int. J. Contemp. Hosp. Manag. 2017, 29, 2322-2340. [CrossRef]

39. Mody, M.A.; Suess, C.; Lehto, X. The Accommodation Experiencescape: A Comparative Assessment of Hotels and Airbnb. Int. J. Contemp. Hosp. Manag. 2017, 29, 2377-2404. [CrossRef]

40. Mudambi, S.M.; Schuff, D. What Makes a Helpful Review? A Study of Customer Reviews on Amazon. Com. Mis Quart. 2010, 34, 185-200. [CrossRef]

41. Cantallops, A.S.; Salvi, F. New Consumer Behavior: A Review of Research on eWOM and Hotels. Int. J. Hosp. Manag. 2014, 36, 41-51. [CrossRef]

42. Tsao, W.; Hsieh, M.; Shih, L.; Lin, T.M. Compliance with eWOM: The Influence of Hotel Reviews on Booking Intention from the Perspective of Consumer Conformity. Int. J. Hosp. Manag. 2015, 46, 99-111. [CrossRef]

43. Xiang, Z.; Schwartz, Z.; Gerdes, J.H., Jr.; Uysal, M. What Can Big Data and Text Analytics Tell Us About Hotel Guest Experience and Satisfaction? Int. J. Hosp. Manag. 2015, 44, 120-130. [CrossRef]

44. Zhou, L.; Ye, S.; Pearce, P.L.; Wu, M. Refreshing Hotel Satisfaction Studies by Reconfiguring Customer Review Data. Int. J. Hosp. Manag. 2014, 38, 1-10. [CrossRef]

45. Tao, S.; Kim, H. Cruising in Asia: What Can We Dig from Online Cruiser Reviews to Understand their Experience and Satisfaction. Asia Pac. J. Tour. Res. 2019, 24, 514-528. [CrossRef]

46. Lee, H.A.; Law, R.; Murphy, J. Helpful Reviewers in TripAdvisor, an Online Travel Community. J. Travel Tour. Mark. 2011, 28, 675-688. [CrossRef]

47. Martin-Fuentes, E.; Fernandez, C.; Mateu, C.; Marine-Roig, E. Modelling a Grading Scheme for Peer-To-Peer Accommodation: Stars for Airbnb. Int. J. Hosp. Manag. 2018, 69, 75-83. [CrossRef]

48. Sparks, B.A.; Browning, V. The Impact of Online Reviews on Hotel Booking Intentions and Perception of Trust. Tour. Manag. 2011, 32, 1310-1323. [CrossRef]

49. Phua, V.C. Perceiving Airbnb as Sharing Economy: The Issue of Trust in Using Airbnb. Available online: https://www.tandfonline.com/doi/full/10.1080/13683500.2018.1440539/ (accessed on 26 December 2018).

50. Wang, Y.; Xiang, D.; Yang, Z.; Ma, S.S. Unraveling Customer Sustainable Consumption Behaviors in Sharing Economy: A Socio-Economic Approach Based on Social Exchange Theory. J. Clean. Prod. 2019, 208, 869-879. [CrossRef]

51. Xiaozhu. Available online: https://www.xiaozhu.com/ (accessed on 26 December 2018).

52. Shen, Y. ROST Content Mining System: Software for Content Mining and Analysis; Wuhan University: Wuhan, China, 2008.

53. Emily Ma, M.C.A.H. Sentiment Analysis—a Review and Agenda for Future Research in Hospitality Contexts. Int. J. Contemp. Hosp. Manag. 2019, 30, 3287-3308.

54. Zhang, X.J.; Li, H.M. Budget Hotel Customer Satisfaction Analysis Based on SERVQUAL Model. Strateg. Manag. Eng. Enterp. Environ. Crisis 2009, 1, 64-68.

55. Kralj, A.; Solnet, D. Service Climate and Customer Satisfaction in a Casino Hotel: An Exploratory Case Study. Int. J. Hosp. Manag. 2010, 29, 711-719. [CrossRef]

56. Liang, L.J.; Choi, H.C.; Joppe, M. Understanding Repurchase Intention of Airbnb Consumers: Perceived Authenticity, Electronic Word-Of-Mouth, and Price Sensitivity. J. Travel Tour. Mark. 2018, 35, 73-89. [CrossRef]

(C) 2019 by the authors. Licensee MDPI, Basel, Switzerland. This article is an open access article distributed under the terms and conditions of the Creative Commons Attribution (CC BY) license (http://creativecommons.org/licenses/by/4.0/). 